\title{
MAINSTREAMING HUMAN RIGHTS
}

\section{THROUGH THE ENLARGEMENT POLICY: THE CASE OF THE WESTERN BALKAN COUNTRIES $S^{1}$}

\section{INTEGRAÇÃO DOS DIREITOS HUMANOS ATRAVÉS DA POLÍTICA DE ALARGAMENTO: O CASO DOS PAÍSES DOS BALCÃS OCIDENTAIS}

\section{Gentjan Skara²}

Licença CC BY:

Artigo distribuído sob os termos Creative Commons, permite uso e distribuição irrestrita em qualquer meio desde que o autor credite a fonte original.

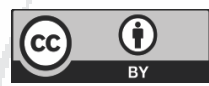

\begin{abstract}
The EU enlargement has been considered as the EU's most efficient foreign policy instrument in terms of its ability to transform communist countries into functional democracies and open market countries. Since the beginning of 1990s, the promotion of human rights has become prominent topic either for the consolidation of human rights within the EU or outside. The argument of this paper is that the EU enlargement policy has influenced Western Balkan countries to improve their domestic legislation in the area of human rights. The paper demonstrates, firstly, how has evolved the EU human rights actorness from the establishment of the EE Community and secondly, discuss strategies and instruments used by the EU to export its norms and values in the Western Balkan countries. The paper addresses the following research question: how, whether and to what extent, the EU has promoted human rights in the Western Balkan countries. Throughout this paper, a doctrinal legal research has been used to analyze EU primary and secondary sources. The value of this paper lies in its comprehensiveness in drawing a complete picture of EU role in promoting human rights in Western Balkan countries through enlargement policy and to discuss the impact of the EU Charter of Fundamental Rights in the candidate countries.
\end{abstract}

This research paper has been written in the framework of Post-Doctoral Researcher 'New Technologies and Law' requirement organized by Mediterranea International Center for Human Rights Research (MICHR), Italy. A first draft of this paper was presented at the International Conference 'I 20 Anni della Carta di Nizza ed il Dialogo tra Europa e America Latina in Materia di Diritti Umani' organised by Mediterranea International Centre for Human Rights Research (Italy); Rede de Pesquisa Direitos Humanos e Transnacionalidade (Brasile) Department of Civil, Economic and Private International Law- Cracow University of Economics (Polonia); Programa de Pós-Graduação em Direito - Universidade de Caxias de Sul (Brasile); Facultad de Derecho-Universidad Central de Ecuador (Ecuador); Facultad de Derecho - Universidad Siglo 21 (Argentina) on 7-8 December 2020.

2 LLB from University of Tirana (Albania); MA in 'European Studies' from Epoka University (Albania) and a LLM for "South East European Law and European Integration" from University of Graz; PhD in "EU Law and National Legal System program' from University of Ferrara. Has been a visiting researcher at the Institute of Corporate and International Commercial Law, University of Graz (Austria) and at the Department of International Law, University of Ljubljana (Slovenia). From October 2012, has been a full-time member of the Department of Law at "Bedër" University College teaching International and EU law courses. Currently, he is attending a Post-PhD Program in 'Law and Technology' at MICHR. Email: gentian.skara@gmail.com. 
Key words: Enlargement Policy; Conditionality; Human Rights Actor; Western Balkan countries; EU Charter of Fundamental Rights

Resumo: O alargamento da UE foi considerado o seu instrumento de política externa mais eficiente, em termos da sua capacidade de transformar os países comunistas em democracias funcionais e países de mercado aberto. Desde o início da década de 1990, a promoção dos direitos humanos tornou-se um tópico proeminente para a consolidação dos direitos humanos dentro ou fora da UE. O argumento deste documento é que a política de alargamento da UE influenciou os países dos Balcãs Ocidentais a melhorar a sua legislação interna na área dos direitos humanos. O documento demonstra, em primeiro lugar, como evoluiu a atuação da UE em direitos humanos desde o estabelecimento da Comunidade Econômica Europeia e, em segundo lugar, discutiu estratégias e instrumentos usados pela UE para exportar suas normas e valores nos países dos Balcãs Ocidentais. O documento aborda a seguinte questão de pesquisa: como, se, e em que medida a UE promoveu os direitos humanos nos países dos Balcãs Ocidentais. Ao longo deste documento, uma pesquisa jurídica doutrinária foi usada para analisar as fontes primárias e secundárias da UE. O valor deste documento reside na sua abrangência em traçar um quadro completo do papel da UE na promoção dos direitos humanos nos países dos Balcãs Ocidentais através da política de alargamento e discutir o impacto da Carta dos Direitos Fundamentais da UE nos países candidatos.

Palavras-chave: Política de Ampliação; Condicionalmente; Ator de Direitos Humanos; Países dos Balcãs Ocidentais; Carta dos Direitos Fundamentais da UE

\section{INTRODUCTION}

The EU Enlargement policy has been considered as the EU's most efficient foreign policy instrument in terms of its ability to transform communist countries into functional democracies and open market countries. As shown in the case of Central European Eastern countries (CEECs), this policy has promoted regional integrations and has had a significant effect on transforming the domestic structure of countries that used to be part of Soviet Union, policies and society at large. ${ }^{3}$

Since the beginning of 1990s, the EU has increasingly emphasized the importance of human rights promotion with third countries. A growing body of academic literature has been written on the incorporation of human rights clauses in bilateral trade and cooperation agreement ${ }^{4}$ as well as association agreement in the framework of the enlargement process. ${ }^{5}$ Furthermore, after the adoption

$3 \quad H$. GRABBE, 'Six lessons of enlargement ten years on: the EU's transformative power in retrospect and prospect' (2014) Vol. 52, Journal of Common Market Studies, pp 40-56; H. GRABBE, The EU's Transformative Power: Europeanization through Conditionality in Central and Eastern Europe, Palgrave Studies in European Union Politics, Palgrave Macmillan, 2006.

4 K. ARTS, Integrating Human Rights into Development Cooperation: The Case of the Lombe Convention, Springer, 2000; V. MILLER, The Human Rights Clause in the EU's External Agreement, House of Commons Library, International Affairs and Defence, 2004; L. BARTEL, Human Rights in the EU's International Agreement, Oxford university Press, 2005; L. BARTEL, Human Rights and Democracy Clauses in the EU's International Agreements, DG for External Policies of the Union, 2005; S. VELLUTI, 'The Promotion and Integration of Human Rights in EU External Trade Relations' (2016) Vol. 32, Utrecht Journal of International and European Law, pp. 41-68.

5 E. FIERRO, The EU's Approach to Human Rights Conditionality in Practice, Martinus Hijhoff Publishers, 2002. 
of the Treaty of Maastricht and especially the birth of CFSP, researcher attention shifted toward the role of the EU as a human rights actor ${ }^{6}$ and its impact as a human rights promoter in the Central Eastern Europe countries. ${ }^{7}$ The argument of this proposal is that the EU enlargement policy has contributed to the promotion of human rights in the Western Balkan countries (WBC). By using the EU conditionality, the WBc have improved their domestic legislation and understanding in the area of human rights. However, this "EU transformative power" as coined by Young, ${ }^{8}$ has been undermined to some extent by WBC domestic constraints such as: i) weakness of state structures or limited statehood in certain contexts; ii) low level of economic growth, high level of unemployment, informal economy, trade deficits and slow liberalisation of the market; ${ }^{9}$ and iii) ineffective law enforcement and high level of corruption. ${ }^{10}$

The paper seeks to analyze how, whether and to what extent, the EU has mainstreamed the promotion of human rights in the Western Balkan countries. In addressing the principal question, the paper considers the following sub-research questions: How has the EU become a human rights actor? What are the main policies that the EU has pursued with the WBc to promote human rights? To which extent the EU has used its instruments in promoting human rights and whether these instruments have been effective? And finally, what is the impact of the Charter of the Fundamental Human on the enlargement process of Western Balkan countries?

The core methodology of this paper is that of traditional legal doctrine, which is based on analyses and interpretation of the EU primary and secondary sources; jurisprudence of CJEU and international agreement concluded by the EU and third countries provisions. Additionally, secondary sources such as book, journal and website articles have been taken into consideration.

This paper is composed of this introduction and five sections. The second section provides an overview of the EEC/EU actorness from an economic organization toward a human rights promoter; followed by third section which rediscovers human rights issues beginning with the Maastricht Treaty and lately with the Lisbon Treaty which gave to the Charter of Fundamental Rights a legal value (third section). The fourth section analyses the Stabilisation and Association Process as an integration mechanism for promotion of human rights in WBC and discusses main instruments used by the EU to promote human rights. The fifth section describes the impact of the Charter of Fundamental Rights in the WBc.

6 A. ROSAS, 'Is the EU a Human rights Organisation' CLEER Working Paper 2011/1; G. de BÚRCA, 'The Road not taken: The European Union as a Global Human Rights Actor' (2011) Vol. 105, The American Journal of International Law, pp. 649-693; J. E. WETZEL (ed), The EU as a "Global Player" in Human Rights? Routledge, 2011.

$7 \quad$ M M. ZOLKOS, 'Bringing Human Rights in the Enlargement Politics: the EU as a Human Rights Promoter in the Central Eastern Europe' [2004] Středoevropské politické studie <https://journals.muni.cz/cepsr/article/ view/4044/5283> accessed 1 March 2021.

8 R. YOUNGS, 'Engaging: sharpening European influence. In New terms of engagement', in Richard Young (ed), Global Europe Report 2: New Terms of Engagement, The Foreign Policy Centre, 2004, p. 5.

9 The World Bank and WIIW, 'Western Balkans Labor Market Trends 2020', SEE Jobs Gateway March 2020, pp. 13-15.

10 B. HAJDINI and G. Skara, 'Lost in Implementation: EU Law Application in Albanian Legal System' (2017) Issue 33, Journal of Legal Studies, pp. 54 - 59; D. LINOTTE, 'Corruption in the Balkans and EU Membership' (BiEPAG BLOG, 21 December 2019) <https://biepag.eu/corruption-in-the-balkans-and-eu-membership/> accessed 21 January 2021. 


\section{FROM AN ECONOMIC ORGANIZATION TOWARD A HUMAN RIGHT PROMOTER}

The status of the human rights in the EU legal system has changed gradually. The European Coal and Steel Community Treaty (ECSC Treaty) established in 1952, did not contain any provision concerning human rights. Such exclusion was understandable due to Treaty nature which were devoted to coal and steel production. As 6 founding members of ECSC treaty preceded with the signature of European Defence Community (EDC) Treaty, it was necessary to have as well a Treaty for political controls of the what to be established "European army". Recognising this fact, Art 38 of EDC Treaty called for the creation of an Assembly 'elected on a democratic basis' to complement the EDC Treaty provisions. ${ }^{11}$ On 10 September 1952, the Foreign Ministers for Foreign Affairs of the ECSC decided to ask the Common Assembly of ECSC to draw up a draft treaty setting up a European Political Community (EPC) within 10 March 1953. ${ }^{12}$ Pursuant to this, an ad hoc Assembly was established under the leadership of Mr. Henry Spaak, comprising representatives from the the six Member States of the ECSC and additional observer members from the Council of Europe and associated nonmember state. ${ }^{13}$ Art 3 of the draft EPC Treaty foresaw to made as an integral part of the treaty the Convention for the Protection of Human and Fundamental Freedoms signed at Rome in November 1950, as well as the Protocol signed at Paris in March 1952 with a primary purpose of promoting human rights, democracy, and the rule of law. ${ }^{14}$ As the EDC Treaty was rejected by France, the same fate followed the EPC Treaty. ${ }^{15}$

Even the EEC Treaty, established in 1957, did not make reference to human rights. Although a very few rights that might be regarded as human rights did appear within the context of internal market, such as the right of free movement of workers (Article $48 \mathrm{EEC}$ ), the freedom to establish a business (Article $52 \mathrm{EEC}$ ), the freedom to provide services (Article $59 \mathrm{EEC}$, and the right to equal pay as between men and women (Article $119 \mathrm{EEC}$ ). The Preamble made a vague reference "to the constant improvement of the living and working conditions of the peoples of the Member States". ${ }^{16}$ Main reasons why fundamental rights were left outside the EEC Treaty are firstly related with the pragmatic approach of the EEC Treaty nature which had an economic character ${ }^{17}$. Common market was perceived "as necessary for rapid economic growth" for economic recovery. ${ }^{18}$ The main task of EEC, as stipulated

11 B. KARP, ‘The Draft Constitution for a European Political Community’ (1954) Vol. 8, International Organization, pp. 181-202.

12 Resolution 14 'Adopted on 10 September 1952 at Luxembourg by the six Ministers for Foreign Affairs' <http://aei. pitt.edu/991/1/political_union_draft_treaty_1.pdf> accessed 22 January 2021, 26

13 Resolution 14, para B.

14 For an overview of EPC Treaty and human right provisions see G. de BÚRCA, 'The Road Not Taken: The European Union as a Global Humanrights Actor' (2011) Vol 105, The American Journal of International Law, pp. 654-664.

15 S. DUKE, The Elusive Quest for European Security, Palgrave Macmillan, 2000, pp. 12-37.

16 Treaty Establishing the European Economic Community (EEC Treaty) [1957] OJ Special edition, recital 3.

17 J. H.H. WEILER, 'Eurocacy and Distrust: Some Questions Concerning the Role of the European Court of Justice in the Protection of Fundamental Human Rights Within the Legal Order of the European Communities' (1986) Vol. 61, Washington Law Review, pp. 1110-1113.

18 D. J. Gerber, 'The Transformation of European Community Competition Law' (1994) Vol. 35, Harvard International Law Journal. p. 102. 
in Art 2, was establishing a common market and progressively approximating the economic policies of the Member States. Secondly, according to the original plan, European cooperation after the second world war was to be part of a broader political project which also comprised an EDC Treaty and an EPC Treaty. ${ }^{19}$ As the draft EPC Treaty was rejected, the human rights issues remained largely absent from the founding Treaties. The ECHR became the only legal instrument for the protection of human rights.

The promotion of human rights with third countries has been gradually incorporated into the EU agenda over a period of time. Firstly, recognition of the fundamental rights within the EEC/EU landscape is attributed to the ECJ role. ${ }^{20}$ In the first case, Stork, ${ }^{21}$ where a coal wholesaler contested a decision by the High Authority of the ECSC that governed the sale of coal, the ECJ refused to consider the argument that the decision breached basic rights that were protected under Arts 2 and 12 of German Basic Law. ${ }^{22}$ The Court held that "The High Authority is not empowered to examine a ground of complaint which maintains that, when it adopted its decision, it infringed principles of German constitutional law". The same approach was followed in Geitling where the Court refused to recognise that fundamental rights enshrined in German Basic law constrained Community powers. ${ }^{23}$

Starting from the mid of 1960s, the Court affirmed that provisions of EEC Treaty can have direct effect in other words be invoked directly by individuals before courts ${ }^{24}$ and that Community law prevails over national legislation in a case of a conflict. ${ }^{25}$ In Stauder (1969), the ECJ held that EU measures 'contain nothing capable of prejudicing the fundamental human rights enshrined in the general principles of Community law and protected by the Court'. ${ }^{26}$ Strauder was the first case where the ECJ affirmed a category of 'general principles of EU law', which included protection of fundamental human rights. ${ }^{27}$ Shortly, in Internationale Handelsgesellschaft, the ECJ held that "respect for fundamental rights forms an integral part of the general principles of Community law protected by the Court of Justice. The protection of such rights, whilst inspired by the constitutional traditions common to the Member states, must be ensured within the framework of the structure and objectives of the Community". ${ }^{28}$

19 E. SPAVENTA, 'Fundamental Rights in the European Union' in Catherine Barnard and Steve Peers (eds), European Union Law, $3^{\text {rd }}$ edition, Oxfrod University Press, 2020, p. 245.

20 The important role played by the ECJ in protection of human rights protection has been analysed by several authors. ECJ is used interchangeable with the Court of Justice introduced by the Lisbon Treaty. For an extensive literature on this topic see: A.M. BURLEY and W. MATTLI, 'Europe Before the Court: A Political Theory of Legal Integration' (1993) Vol. 47, International Organization, pp. 41-76; F. SCHIMMELFENNING, 'Competition and community: constitutional courts, rhetorical action, and the institutionalization of human rights in the EU Union' (2006) Vol. 13, Journal of EU Public Policy, pp. 1247-1264.

21 Judgment of 4 February 1959, Storck v Haute autorité, C-1/58, ECLI:EU:C:1959:4.

22 Judgment of 4 February 1959, Storck v Haute autorité, C-1/58, ECLI:EU:C:1959:4, para 4 (a).

23 Judgment of 15 July 1960, Präsident Ruhrkohlen-Verkaufsgesellschaft and Others v High Authority, C-36-38/59 and C-40/59, ECLI:EU:C:1960:36.

24 Judgement of 5 February 1963, NV Algemene Transport- en Expeditie Onderneming van Gend \& Loos v Netherlands Inland Revenue Administration, C-26/62, ECLI:EU:C:1963:1.

25 Judgement of 15 July 1964, Flaminio Costa v E.N.E.L., C-6/64, [1964] ECLI:EU:C:1964:66.

26 Judgment of 12 November 1969, Stauder v Stadt Ulm, C-29/69, ECLI:EU:C:1969:57, para 7.

27 P. CRAIG and G. de BÚRCA, EU Law: Text, Cases, and Materials, $7^{\text {th }}$ edn, Oxford University Press, p. 417.

28 Judgment of 17 December 1970, Internationale Handelsgesellschaft mbH v Einfuhr- und Vorratsstelle für Getreide und Futtermittel, C-11/70, ECLI:EU:C:1970:114, para 4. 
In Nold, a case concerning the drastic impact on the applicant's right to a livelihood of the EU's regulation of the market in coal, the Court identified common national constitutional traditions and international human rights agreements on which the Member States have collaborated or of which they are signatories as sources of "inspiration" for the general principles of EU law. ${ }^{29}$ A year later, in Rutili concerning the reviewed certain limitations placed on the powers of Member States in respect of control of aliens by Council Directive 64/22130 and Regulation 1612/68, ${ }^{31}$ the ECJ indicated that when Member States are applying provisions of EU legislation which are based on protection for human rights, they are bound by the general principles enshrined in the European Convention of 1950 for the Protection of Human Rights and Fundamental Freedoms. ${ }^{32}$

From then on, the ECJ has played an important role as promoter of human rights until the entering into force of the EU Charter of Fundamental Rights touching on issues relating to: the right to human dignity; ${ }^{33}$ the right to physical integrity; ${ }_{i}^{34}$ the right to marry; ${ }_{i}^{35}$ the right not to be discriminated against; ${ }^{36}$ the right to a fair hearing; ${ }_{i}^{37}$ the right to a legal remedy; ${ }^{38}$ the right not to be convicted of an offence created retrospectively; ${ }^{39}$ the right to good administration; ${ }^{40}$ the right to respect for religion and belief; ${ }^{41}$ the right to freedom of expression; ${ }^{42}$ the right to freedom of assembly; ${ }^{43}$ the right to peaceful enjoyment of property; ${ }_{i}^{44}$ and the right to freedom to pursue a trade or profession. ${ }^{45}$

While the ECJ codified human rights as a "general principles of Community Law", the massacre that took place in Uganda when hundreds of thousands of people were killed, ${ }^{46}$ brought into the agenda of a European Parliament the opportunity to include a human rights clause on international trade agreement. ${ }^{47}$ As an outcome of criticism toward EC financial assistance toward Uganda based

29 Judgment of 14 May 1974, Nold KG v Commission, C-4/73, ECLI:EU:C:1974:51, para 13.

30 Council Directive 64/221/EEC of 25 February 1964 on the co-ordination of special measures concerning the movement and residence of foreign nationals which are justified on grounds of public policy, public security or

31 Regulation (EEC) No 1612/68 of the Council of 15 October 1968 on freedom of movement for workers within the Community [1968] OJ Special edition.

32 Judgment of 28 October 1975, Rutili v Ministre de l'intérieur. C-36/75, ECLI:EU:C:1975:137, para 32.

33 Judgment of 14 October 2004, Omega, C-36/02, ECLI:EU:C:2004:614

34 Judgment of 18 September 1992, X v Commission, joined cases T-121/89 and T-13/90, ECLI:EU:T:1992:96.

35 Judgment of 17 February 1998, Grant v South West Trains Ltd, C-249/96, ECLI:EU:C:1998:63.

36 Judgment of 20 March 1984, Razzouk and Beydoun v Commission, Joined Cases C-75/82 and C-117/82, ECLI:EU:C:1984:116.

37 Judgment of 7 June 1983, Musique Diffusion Française v Commission, Joined cases C-100-103/80, ECLI:EU:C:1983:158.

38 Judgment of 15 May 1986, Johnston v Chief Constable of the Royal Ulster Constabulary, C-222/84, ECLI:EU:C:1986:206.

39 Judgment of 12 December 1996, X, Joined Cases C-74/95 and C-129/95, ECLI:EU:C:1996:491.

40 Judgment of 6 February 1986, Castille v Commission, Joined cases C-173/82, C-157/83 and C-186/84, ECLI:EU:C:1986:54.

41 Judgment of 27 October 1976, Prais v Council, C-130/75, ECLI:EU:C:1976:142.

42 Judgment of 13 December 1989, Oyowe and Traore v Commission, C-100/88, ECLI:EU:C:1989:638.

43 Judgment of 8 July 1999, P Montecatini SpA v Commission, C-235/92, ECLI:EU:C:1999:362.

44 Judgment of 14 May 1974, Nold KG v Commission, C-4/73, ECLI:EU:C:1974:51; Judgment of 13 December 1979, Hauer v Land Rheinland-Pfalz, C-44/79, ECLI:EU:C:1979:290.

45 Judgment of 8 October 1986, Staatsanwalt Freiburg v Keller, C-234/85, ECLI:EU:C:1986:377.

46 L. BARTEL, Human Rights in the EU's International Agreement, Oxford university Press, 2005, p. 7.

47 A. MOBERG, 'What Constitutes a Breach of the EC's Conditionality Clause? <https://gup.ub.gu.se/v1/asset_ data/206701> accessed 29 December 2020, pp. 1-3. 
on the first Lomé Convention in $1975,{ }^{48}$ the Council, in 1977, declared suspension of relations in the case of infringement of human rights stating that:

The Council agrees to take steps within the framework of its relationship with Uganda under the Lomé Convention to ensure that any assistance given by the Community to Uganda does not in any way have as its effect a reinforcement or prolongation of the denial of basic human rights to its people ${ }^{49}$.

Despite the non-binding effects of "Uganda Guidelines", the suspension shaped to a great extent the EEC philosophy for external actions by provoking 'the idea of including a human right clause in a newly-negotiated agreement'..$^{50}$ After a lot of discussion and negotiations, the Conclusion of the Lomé IV Convention in 1989 marked the first agreement that included a human rights clause. ${ }^{51}$ Article 5 of the Lomé IV Convention stipulated that:

1. Cooperation shall be directed towards development centred on man, the main protagonist and beneficiary of development, which thus entails respect for and promotion of all human rights. Cooperation operations shall thus be conceived in accordance with the positive approach, where respect for human rights is recognized as a basic factor of real development and where cooperation is conceived as a contribution to the promotion of these rights. In this context development policy and cooperation are closely linked with the respect for and enjoyment of fundamental human rights.

Article 5 of the Lomé IV agreement "put on paper an idea that had been latent in the mind of the Community in the past decades and, in this manner, it established the precedent" ${ }^{\prime \prime 2}$. Since then, the EU has insisted on inclusion of the human rights clauses in trade and cooperation agreements of a general nature with Latin American Continent and later the democratisation process in Central and Eastern Europe ${ }^{53}$.

\section{REDISCOVERING HUMAN RIGHTS: FROM MAASTRICHT TREATY TO THE CHARTER OF FUNDAMENTAL RIGHTS OF THE EUROPEAN UNION}

The Treaty of Maastricht, which entered into force on 1 November 1993, marked the Union ambition to articulate a common foreign policy objective towards more "effective international actorness" 54 . This momentum broadened the EU's discourse in human rights by moving the Union toward a political organization. Since the Maastricht Treaty, the promotion of human rights has evolved in two aspects.

48 ACP-EEC First Convention signed at Lomé on 28 February 1975, OJ L 025, 30/01/1976.

49 Council Declaration on the situation in Uganda, 21 June 1977, Bull. EC, 6-1977, 2.2.59, 77-78.

50 E. FIERRO, The EU's Approach to Human Rights Conditionality in Practice, Martinus Hijhoff Publishers, 2002, p. 42.

51 ACP-EEC Fourth Convention signed at Lomé on 15 December 1989 [1991] OJ L 229.

52 E. FIERRO, The EU's Approach to Human Rights Conditionality in Practice, Martinus Hijhoff Publishers, 2002, p. 216.

53 M. BULTERMAN, Human Rights in the Treaty Relations of the European Union, Insertia, 2001.

54 K. E. SMITH, European Union Foreign Policy in a Changing World, $3^{\text {rd }}$ edition, Polity Press, 2014 , p. 3. 
Internally, for the first time the TEU introduced weak provisions in the pursuit of a human rights policy. According to Article F (2):

The Union shall respect fundamental rights, as guaranteed by the European Convention for the Protection of Human Rights and Fundamental Freedoms signed in Rome 4 November and as they result from the constitutional traditions common to the Member States as general principles of Community Law.

Moreover, the Treaty of Amsterdam introduced Article F1 TEU by emphasizing the values on which the Union is founded. ${ }^{55}$ The EU values as defined in Article F1 TEU (now Art 2 TEU) constituted the foundation of integration by returning back the founding ideals and rationales laid down during the travaux preparatoires of EPC Treaty. ${ }^{56}$ Another important development was the adoption of the EU Charter of Fundamental Rights (EU Charter), as a non - legal document (2000). Despite not legally binding effect, the EU Charter has a real significance because: "it constitutes the expression, at the highest level, of a democratically established political consensus on what must today be considered as the catalogue of fundamental rights guaranteed by the Community legal order". ${ }^{57}$ The Lisbon Treaty, which entered into force in 2009, introduced the EU Charter as a binding document (Article 6 TEU). Moreover, it reinforced the premise that the EU is based on values and principles that are common to all Member States (Article 2 TEU). Thus, respect for human rights is a value upon which the European Union is founded. Moreover, the respect for human rights is also a precondition for an aspirant state to be considered as a candidate for the EU membership (Art 49 TEU). ${ }^{58}$

Externally, the Treaty of Maastricht introduced two references on human rights. The first reference related to one objective of the CFSP that "shall be to develop and consolidate democracy and the rule of law, and respect for human rights and fundamental freedoms". ${ }^{59}$ The second reference is related within the framework of the provisions on developing cooperation. According to Article $130(u)$, "the Community policy in this area [development cooperation] shall contribute to the general objective of developing and consolidating democracy and the rule of law, and to that of respecting human rights and fundamental freedom and fundamental freedoms". While provisions concerning human rights were included, the TEU did not stipulate any instrument to translate these principles into actual policies. ${ }^{60}$

55 Treaty of Amsterdam amending the Treaty on European Union, the Treaties establishing the European Communities and certain related acts - Final Act [1997] OJ C 340/01. Article F1 of the TEU reads as follows: "The Union is founded on the principles of liberty, democracy, respect for human rights and fundamental freedoms, and the rule of law, principles which are common to the Member States".

56 G. de BÚRCA, 'The Road not taken: The European Union as a Global Human Rights Actor' (2011) Vol. 105, The American Journal of International Law, pp. 654-664.

57 Opinion of Advocate General Mischo delivered on 20 September 2001, Booker Aquaculture Ltd trading as Marine Harvest McConnell and Hydro Seafood GSP Ltd v The Scottish Ministers, Joined Cases C-20/00 and C-64/00, ECLI:EU:C:2001:469, para 126.

58 European Council, 'Conclusion of the Presidency' (SN 180 / 1 / 93 Rev 1, 21 - 22 June 1993), <http://www. consilium.europa.eu/ueDocs/cms_Data/docs/pressData/en/ec/72921.pdf> accessed 31 January 2021 pt 7A (iii).

59 The Treaty on European Union, as signed in Maastricht on 7 February 1992, Art J.1 (1).

60 A. MAMMADOV, 'Human Rights Promotion in the EU Foreign Policy' (Global Politics, 28 August 2010) <http:// www.globalpolitics.cz/clanky/human-rights-promotion-in-the-eu-foreign-policy> accessed 29 December 2020. 
The Treaty of Lisbon considers upholding fundamental rights as the most effective instruments for spreading democracy, rule of law, promotion of human rights and protection of minorities and other values on which the Union is founded in third countries. Article 3 (5) TEU reveals the guiding principles for the external actions that shall be mutatis mutandis the same as for the internal relations. This article was further elaborated in article 21 TEU stating that "The Union's action on the international scene shall be guided by the principles which have inspired its own creation, development and enlargement, and which it seeks to advance in the wider world [ ...] indivisibility of human rights". The following paragraph (Article 21(2)-(b) TEU), stipulates that when defining common policies of external action, the Union is to "consolidate and support democracy, the rule of law, human rights and the principles of international law".

\section{THE STABILISATION AND ASSOCIATION PROCESS AS AN INTEGRATION MECHANISM FOR PROMOTION OF HUMAN RIGHTS IN WESTERN BALKAN COUNTRIES}

Following the cessation of the Kosovo conflict, the EU introduced a new policy for the region, named Stabilisation and Association Process (SAP), with the purpose to bring these countries closer to the EU. ${ }^{61}$ A year later, the EU recognized all WBC as potential candidates for EU membership ${ }^{62}$ and committed its wish "to contribute to the consolidation of democracy and to give its resolute support to the process of the reconciliation and cooperation between the countries concerned". ${ }^{63}$

While the EU reaffirmed the prospect of EU membership, criteria based on which the enlargement of the $\mathrm{WBC}$ shall proceed remained undefined. The turning point occurred in the Thessaloniki Summit (2003) where the EU declared "unequivocal support to the European perspective of the Western Balkan countries. The future of the Balkans is within the European Union". ${ }^{64}$ Such declaration shifted the EU approach from post-conflict stabilisation to European integration as the final aim, by reaffirming that the future of the Balkans is within the European Union once the same conditions and requirements applied to the CEECs are fulfilled. The SAP is composed of four key components: (a) the establishment of contractual relationships between the EU and the Western Balkans countries in the form of stabilisation and association agreements (SAA); (b) providing financial assistance; (c) asymmetrical trade preferences; and d) the promotion of regional cooperation and good neighbourly relations.

61 Commission Communication to the Council and the European Parliament on the Stabilization and Association process for Countries of South - Eastern Europe [1999] COM 235.

62 European Council, 'Santa Maria da Feira European Council: Conclusions of the Presidency' (19 and 20 June 2000) <https://www.europarl.europa.eu/summits/fei1_en.htm> accessed 22 January 2021.

63 Zagreb Summit, (Final declaration, November 2000) <http://www.consilium.europa.eu/ueDocs/cms_Data/docs/ pressdata/en/er/Declang4.doc.html> accessed 20 January 2021, para 4

64 Council of the European Union, Thessaloniki European Council 19 and 20 June 2003 Presidency Conclusions, Brussels, 1 October 2003. 
Within the enlargement process, conditionality has become a key instrument for accession to assist and facilitate the comprehensive reform process of countries aspiring to join the EU membership. ${ }^{65}$ Kubicek defines conditionality as "the linking of perceived benefits (e.g. political support, economic aid, membership in an organisation) to the fulfilment of a certain programme, in this case the advancement of democratic principles and institutions in a "target" state". 66 Thus conditionality is meant to be effective "only if a recipient country undertakes a policy change that would not have undertake by itself" ${ }^{67}$

While the previous enlargements were carried out in the absence of a clearly defined criteria, the situation changed with the aspiration of CEECs to join the EU. ${ }^{68}$ In June 1993, the European Council took the commitment that "accession will take place as soon as an associated country is able to assume the obligations of membership by satisfying the economic and political conditions required". ${ }^{69}$ In order for a country to be able to accede to the EU, it has to demonstrate the fulfilment of, what have been referred to as, the Copenhagen Criteria,

that the candidate country has achieved stability of institutions guaranteeing democracy, the rule of law, human rights and respect for and protection of minorities, the existence of a functioning market economy as well as the capacity to cope with competitive pressure and market forces within the Union. Membership presupposes the candidate's ability to take on the obligations of membership including adherence to the aims of political, economic and monetary union. The Union's capacity to absorb new members, while maintaining the momentum of European integration, is also an important consideration in the general interest of both the Union and the candidate countries. ${ }^{70}$

The Copenhagen criteria were further developed by the Madrid European Council in 1995. The Council confirmed the enlargement of the EU toward CEECs and established that EU membership entails institutional administrative changes for the candidate countries. Adjustment of administrative structure became an added condition for the approximation and effective implementation of EU acquis. ${ }^{71}$ Since 1993, the "Copenhagen criteria" remained the key benchmark for the assessment of candidate countries' progress.

65 O. ANASTASAKIS, 'The Europeanization of the Balkans' (2005) Vol.12, The Brown Journal of World Affairs, p. 78.

66 P. J. KUBICEK, 'International Norms, the European Union, and Democratization: Tentative Theory and Evidence' in Paul J Kubicek (ed), The European Union and Democratization, Routledge, 2003, p. 7.

67 P. UVIN, 'Do as I say, not as I do: The Limits of Political Conditionality' in George Sorensen (ed), Political Conditionality, Frank Cass, 1993, p. 74.

68 F. EMMERT and S. PETROVIĆ, 'The Past, Present, and Future of EU Enlargement' (2014) Vol. 37, Fordham International Law Journal, pp.1349-1419.

69 European Council, 'Conclusion of the Presidency' (SN 180 / 1 / 93 Rev 1, 21 - 22 June 1993), <http://www. consilium.europa.eu/ueDocs/cms_Data/docs/pressData/en/ec/72921.pdf> accessed 31 January 2021 pt 7A (iii).

70 European Council, "Conclusion of the Presidency 21-22 June 1993", pt. 7A (iii).

71 European Council, "Presidency Conclusion" (Madrid, 15 and 16 December 1995) <http://www.consilium.europa. eu/uedocs/cms_data/docs/pressdata/en/ec/00400-C.EN5.htm> accessed 14 February 2021. 
The mandatory inclusion of conditionality into the enlargement process of CEE countries demonstrated the EU commitment to play an "indispensable role" of the EU as a promoter of human rights and became reference for future enlargements. Reading together treaty provisions on enlargement (Arts 49 and 2 TEU) and Copenhagen criteria, it is evident that one aspect of conditionality aims to promote respecting fundamental rights and minorities in the candidate countries. The EU has placed protection of human rights and promotion of rule of law on the center of the enlargement process. According to Smith, the EU has in its disposal various instruments such as: i) the human rights clause in the SAA, ii) the financial aid within accession process to improve or promote human rights, iii) the use of diplomatic instruments (démarches and/or political dialogue) and iv) the deployment of civilian and military missions. ${ }^{72}$ However, two most important instruments are: i) human right clause introduced in SAA and b) financial assistance.

Firstly, all the WBc, under Article 217 TFEU, have signed a Stabilisation and Association Agreement (SAA) with the EU and EU Member States. The SAA builds the legal basis for accession procedures and therefore also sets the frame for policies and measures implemented by the EU in the fields of, inter alia, democratisation and human rights. Aims of the agreement, as defined in Article 1 of all SAA signed with WBC, include "supporting the efforts to strengthen democracy and the rule of law". By signing the SAA, all the WBc, inter alia, have committed themselves to respect human rights including the rights of persons belonging to national minorities.

All the SAAs assert a reference to the commitment of the parties (the EU and candidate countries) to respect human rights and rule of law, including the rights of persons belonging to national minorities. Furthermore, all the SAAs contain "a human right clause" that constitutes an essential element of this agreement. Accordingly,

Respect for democratic principles and human rights as proclaimed in the Universal Declaration of Human Rights and as defined in the Convention for the Protection of Human Rights and Fundamental Freedoms, in the Helsinki Final Act and the Charter of Paris for a New Europe, [...], shall form the basis of the domestic and external policies of the Parties and constitute essential elements of this Agreement ${ }^{73}$.

As can be seen, the respect of human rights constitutes an essential element of this agreement. The breach of this element entails negative measures for the $\mathrm{WBc}$. Therefore, all countries should respect democratic principles and human rights proclaimed in the UDHR, the ECHR and other numerous OSCE documents. It should be noted that the EU Charter has not been mentioned because at the time when these SAAs were negotiated and signed, the EU Charter did not have a binding character.

72 K. E. SMITH, European Union Foreign Policy in a Changing World, $3^{\text {rd }}$ edition, Polity Press, 2014, p. 109.

73 All the SAAs, except Kosovo, contain the general clause of human rights in Article 2, whereas SAA signed with Kosovo contain such clause in Art 3. 
Moreover, all SAAs signed with WBC contain the same approximation provisions that require to ensure that its existing laws and future legislation shall be gradually made compatible with the EU acquis. ${ }^{74}$ For instance, Art 70 (1) of SAA with $\mathrm{BiH}$ provides that:

The Parties recognise the importance of the approximation of the existing legislation of Bosnia and Herzegovina to that of the Community and of its effective implementation. Bosnia and Herzegovina shall endeavour to ensure that its existing laws and future legislation will be gradually made compatible with the Community acquis. Bosnia and Herzegovina shall ensure that existing and future legislation will be properly implemented and enforced.

While legally speaking, the reference to "shall endeavour" provides a voluntarily harmonization, in practice, endeavours clauses contained in the approximation provision of SAA are a precondition for accession confirmed by the Copenhagen Summit and embodied in Article 49 of TEU stating that -the conditions of eligibility agreed upon by the European Council shall be taken into account. ${ }^{75}$ Therefore, approximation of laws has a particular importance for the candidate countries wishing to join the EU because they have to approximate domestic legislation with that of the EU. Pursuant to this obligation stemming from SAA, all the WBc have begun revising their legal systems so as to align themselves with EU acquis. Secondly, the EU has promoted human rights even through financial aid. The EU financial aid is a strong leverage of the EU to support candidate countries to meet the criteria of accession. ${ }^{76}$ Since 1991, the EU has used different types of financial instruments. The first instrument, PHARE, which served as the main pre-accession strategy guiding CEECS toward European membership, focused on economic restructuring, institutions and capacitybuilding, and investment financing of the WBc. ${ }^{77}$ From 2000, the EU introduced, as part of the SAP framework, a single legal framework for Community assistance for all the WBc and to be more structured than the previous programme (CARDS). ${ }^{78}$ For a period 2000-2006, the CARDS programme allocated 4650 EUR million. In contrast from the PHARE programme, the CARDS aimed, inter alia, to build up an institutional and legislative to support democracy, the rule

74 Stabilisation and Association Agreement between the European Communities and their Member States, of the one part, and the former Yugoslav Republic of Macedonia, of the other part, [2004] OJ L 84/13, Art 68; Stabilisation and Association Agreement between the European Communities and their Member States, of the one part, and the Republic of Albania, of the other part [2009] OJ L 107/166, Art 70; Stabilisation and Association Agreement between the European Communities and their Member States of the one part, and the Republic of Serbia, of the other part [2013] OJ L 278/16, Art 72; Stabilisation and Association Agreement between the European Union and the European Atomic Energy Community, of the one part, and Kosovo*, of the other part [2016] OJ L 71/3; Stabilisation and Association Agreement between the European Communities and their Member States of the one part, and the Republic of Montenegro, of the other part [2010] OJ L108/3, Art 72; Stabilisation and Association Agreement between the European Communities and their Member States, of the one part, and Bosnia and Herzegovina, of the other part [2015] OJ L 164/2, Art 70.

75 B. HAJDINI and G. Skara, 'Lost in Implementation: EU Law Application in Albanian Legal System' (2017) Issue 33, Journal of Legal Studies, p. 48.

76 G. SKARA, 'The Role of The Role of the EU as a Peacebuilder in the Western Balkans' (2014) Vol. 14, Romanian Journal of European Affairs, p. 38.

77 Council Regulation (EEC) No 3906/89 of 18 December 1989 on economic aid to certain countries of Central and Eastern Europe [1989] OJ L 375/11.

78 Council Regulation (EC) No 2666/2000 of 5 December 2000 on assistance for Albania, Bosnia and Herzegovina, Croatia, the Federal Republic of Yugoslavia and the Former Yugoslav Republic of Macedonia, repealing Regulation (EC) No 1628/96 and amending Regulations (EEC) No 3906/89 and (EEC) No 1360/90 and Decisions 97/256/EC and 1999/311/EC [2000] OJ L 306/1. 
of law and human and minority rights which were considered as "an essential element for the application of this Regulation and a precondition of eligibility for Community assistance" ${ }^{79}$

After 2006, the EU supported WBc accession process under IPA I (2006-2013) and IPA II (20142020). For the period 2007-2013, IPA I had a budget of some $€ 11.5$ billion; 80 whereas the IPA II allocated $€ 11.7$ billion. ${ }^{81}$ One of the objectives of IPA I and currently IPA II is supporting political reforms in candidate countries, inter alia, through:

promotion and protection of human rights and fundamental freedoms, enhanced respect for the rights of persons belonging to minorities, including lesbian, gay, bisexual, transgender and intersex persons, promotion of gender equality, nondiscrimination and tolerance, as well as freedom of the media and respect for cultural diversity. ${ }^{82}$

IPA I in Art 21 provided that respect for the principles of democracy, the rule of law and for human rights and minority rights and fundamental freedoms constitutes an essential element for the allocation of financial aid, whereas the IPA II financial instruments did not contain any explicit reference for the possibility of suspending assistance. However, it should be noted that if the WBc do not respect human rights, the suspension of financial aid is still possible under the conditions set out in the statement attached to the IPA II Regulation. ${ }^{83}$

While the EU emphasized its importance to promotion of rule of law during accession negotiations, in contrast to previous enlargement rounds, the EU adopted a more comprehensive strategy by emphasizing central to accession the political criteria related to democracy, rule of law and human rights and reforms in the economic sphere. ${ }^{84}$ In this context, the 2013 Enlargement Strategy ${ }^{85}$ reflected lessons learned from accession of Bulgaria, Rumania and lately Croatia that chapters 23 "Judiciary and Fundamental Rights" and 24 "Justice, Freedom and Security" had to be addressed in the beginning of negotiations since these countries suffer from lack of democracy, absence of rule of law and human rights. ${ }^{86}$ In 2015, the Commission updated the enlargement strategy with the purpose to strengthen the approach of assessment in its annual reports by providing clearer guidance for what the countries are expected to do in both the short and long

79 Read jointly Arts 2 (2)(a) and 5 of the Council Regulation (EC) No 2666 / 2000.

80 Council Regulation (EC) No 1085/2006 of 17 July 2006 establishing an Instrument for Pre-Accession Assistance (IPA) [2006] OJ L 210/82, Art 26.

81 Regulation (EU) No 231/2014 of the European Parliament and of the Council of 11 March 2014 establishing an Instrument for Pre-accession Assistance (IPA II) [2014] L 77/11, Art 15.

82 Regulation (EU) No 231/2014 of the European Parliament and of the Council of 11 March 2014 establishing an Instrument for Pre-accession Assistance (IPA II) [2014] OJ L 77/11, Art 2 (1) (a) ii.

83 'Statement by the European Parliament on the suspension of assistance granted under the financial instruments' included in the Regulation (EU) No 231/2014.

84 G. SKARA, 'The Rocky Road of Western Balkan Countries toward European Integration: The Need for a Credible and Effective Approach' (2020) Vol.3, Journal of European Social Research, p. 5.

85 Commission, 'Enlargement Strategy and Main Challenges 2013-2014' (Communication from the Commission to the European Parliament and The Council) COM (2013) 700 final.

86 A. L. DIMITROVA, 'The EU's Evolving Enlargement Strategies: Does Tougher Conditionality Open the Door for Further Enlargement?', Working Paper SERIES 30, MAXCAP, 2016, p. 10. 


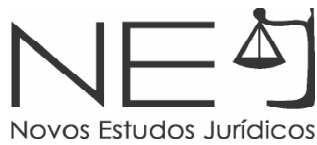

term. ${ }^{87}$ Again in 2018, a new enlargement strategy was issued purposely to reinvigorate the process as that that all "the countries show clear elements of state capture, including links with organised crime and corruption at all levels of government and administration, as well as a strong entanglement of public and private interests" ${ }^{88}$ The latest Enlargement Strategy, published on 5 February 2020,89 "reestablish a credible EU perspective for the Western Balkans". ${ }^{90}$ Instead of 35 chapters of negotiations, the new enlargement methodology structures the EU acquis in 6 clusters. Again, at the heart of accession remains promotion of human rights, democracy and rule of law as a first cluster titled "Fundamentals". Negotiation on the "Fundamentals" would be open in the beginning of the opening of the negotiations and closed once all the criteria fulfilled. ${ }^{91}$

As noted by 2020 EC Enlargment Strategy, all WBc have approximated their legislation in line with EU acquis on fundamental rights, but still implementation remains a challenge in practice..$^{92}$ Main reason of such failure refers to the weakness of state structures or limited statehood in certain contexts; ${ }^{93}$ to national identities conflicting with goals pursued during enlargement process; ${ }^{94}$ to the various sources of inconsistencies on the side of the EU in the enlargement context; 95 and low level of economic growth, high level of unemployment, informal economy, trade deficits and slow liberalisation of the market. ${ }^{96}$

\section{IMPACT OF THE CHARTER OF FUNDAMENTAL RIGHTS IN THE WBC}

The adoption of the EU Charter constitutes the most significant step in the history of the EU. The EU Charter draws heavily from the ECHR, the constitutional traditions of member states, the international conventions to which member states belong and case law of the Court of Justice ${ }^{97}$. In the beginning the EU Charter was presented as a non-binding document, but later, with the Treaty of

87 Commission, 'EU Enlargement Strategy' (Communication from the Commission to the European Parliament, the Council, the European Economic and Social Committee and the Committee of the Regions) COM (2015) 611 final, p. 4.

88 Commission, 'EU Enlargement Strategy' (Communication from the Commission to the European Parliament, the Council, the European Economic and Social Committee and the Committee of the Regions) COM (2015) 611 final, p. 3.

89 Commission, 'A more credible, dynamic, predictable and political EU accession process - Commission lays out its proposals' (Press release, 5 February 2020) <https://ec.europa.eu/commission/presscorner/detail/ en/IP_20_181> accessed 6 February 2020

90 Commission, 'Remarks by Commissioner Olivér Várhelyi at the press conference on the revised enlargement methodology' <https://ec.europa.eu/commission/presscorner/detail/en/statement_20_208> accessed 6 February 2020.

91 Commission, 'Enhancing the accession process - A credible EU perspective for the Western Balkans' (Communication) COM(2020) 57 final, p. 7.

92 Commission, 2020 Communication on EU enlargement policy [2020] COM(2020) 660 final, p. 6.

93 F. BIEBER, 'Building Impossible States? State-Building Strategies and EU Membership in the Western Balkans' (2011) Vol. 63, Europe-Asia Studies, pp. 1783 - 1802.

94 V. DŽIHIĆ and A. WIESER, 'Incentives for Democratisation? Effects of EU Conditionality on Democracy in Bosnia \& Hercegovina' (2011) Vol. 63, Europe-Asia Studies, pp. 1803-1825.

95 Z. KÖRTVÉLYESI, 'Inconsistency and Criticism: Mapping Inconsistency Arguments Regarding Human Rights Promotion in EU External Relations' (2016) European Yearbook of Human Rights, pp. 223-242

96 The World Bank and WIIW, 'Western Balkans Labor Market Trends 2020', SEE Jobs Gateway, March 2020, pp. 13-15

97 EU Charter of Fundamental Rights, Recital 5. 
Lisbon, was introduced as a legally binding document. The purpose of the EU Charter was to make the existing rights, which the EU institutions, bodies and MS ought to respect, more visible. ${ }^{98}$ The need for a single document, endorsed by EU Member States and EU institutions, was summarized by Lord Goldsmith in his article as follow:

First, the purpose was to deepen and strengthen the culture of rights and responsibilities in the EU. Bringing together in a single document, endorsed by Member States and Community institutions a proclamation of existing rights will have a powerful effect in reinforcing in the minds of administrators, governments and legislators the rights that the citizens possess and the need to respect them. The second purpose was to remedy this lack of clarity in the protection of human rights by declaring clearly which were the rights, freedoms and principles the Union is to respect ${ }^{99}$.

The EU Charter is the first binding document relating with human rights developed explicitly for the EU. By virtue of Article 6 (1) TEU, the EU Charter is part of the EU primary law and will be subject to the jurisdiction of EUCJ. The EU Charter contains 54 Articles distributed on 6 substantive Chapters which are structured as follows: Human Dignity (Arts. 1-5), Freedoms (Arts. 6-19), Equality (Arts. 2026), Solidarity (Arts. 27-38) and Citizenship rights (Arts. 39-50). A final chapter (Arts. 51-54) concerns general rules on its interpretation and scope. The EU Charter applies to the European institutions and the Member States only when they are applying EU law and not otherwise (Art. 51), and that the EU Charter in no way confers new competencies on the EU (Art. 52). The EU Charter closely follows the ECHR to which all EU Member States are signatory parties. According to Berry et al, Titles I (Dignity), II (Freedoms) and VI (Justice) of the Charter largely reflect the same civil and political rights contained in the ECHR with some exception in Title II for example, the right to data protection, the right to work, and the freedom to conduct a business which are not foreseen in the ECHR. ${ }^{100}$ In this context, according to Art 52 (3) the EU Charter rights deriving from the ECHR must be interpreted consistently with the ECHR. Thus, the EU Charter treats the ECHR as a minimum standard of fundamental right protection in the EU.

The same approach has been maintained as well by the EUCJ. In DEB Deutsche Energiehandelsund Beratungsgesellschaft, which concerned the right to legal aid in Article 47 of the EU Charter, the Court of Justice noted that the Explanation on Article 52 (3) of the EU Charter required that "the meaning and scope of the [Charter] rights are to be determined not only by reference to the text of the ECHR, but also, inter alia, by reference to the case-law of the European Court of Human Rights" ${ }^{101}$ Moreover, by virtue of Article 53, the EU Charter is never supposed to curtail rights conferred by the

98 European Council, 'Cologne European Council 3-4 June 1999' (Conclusions of the Presidency) <https://www. europarl.europa.eu/summits/kol1_en.htm> accessed 2 February 2021, para 44 ..

99 Lord GOLDSMITH QC, 'A Charter of Rights, freedoms and principles' (2001) Vol. 38, Common Market Law Review, p. 1216.

100 E. BERRY, M. J. HOMEWOOD, and B. BOGUSZ, Complete EU Law: Text, Cases, and Materials, Oxford University Press, 2019, p. 416; pp. 431-432.

101 Judgment of 22 December 2010, DEB Deutsche Energiehandels- und Beratungsgesellschaft mbH v Bundesrepublik Deutschland, C-279/09, ECLI:EU:C:2010:811, para 35. 


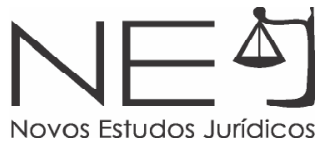

ECHR. Furthermore, it is clear that where EU law - and by extension the EU Charter - applies, the Charter sets the minimum standard of fundamental rights protection. However, as decided by the Court of Justice in Melloni, the EU Charter only allows for a higher level of protection if "the primacy, unity and effectiveness of EU law are not thereby compromised". ${ }^{102}$

According to Art 51 (1), the EU Charter addresses the institutions, bodies, offices and agencies of the Union when they are implementing Union law. While the field of application of the EU Charter is for the internal dimensions, it should be noted that these actors are as well to be bound by the status of the EU Charter when acting in the context of the external dimensions. ${ }^{103}$ Furthermore, the external dimensions seem to be implied in several provisions of the EU Charter. For instance, Article 2 (2) stipulates that "No one shall be condemned to the death penalty, or executed". This provision refers more to the objectives pursued under CFSP (art 21) rather to the EU Member States which are members and have ratified Protocol No 6 of the European Convention of Human Rights. Moreover, there are other implied provisions relating to the external dimension such as: Art 15 (3) "Working conditions of the nationals of third countries"; Art 18 "Right of Asylum" and Art 19 "Protection in the event of removal, expulsion or extradition".

The EU Charter makes no reference to candidate countries. In its preamble states that:

The peoples of Europe, in creating an ever closer union among them, are resolved to share a peaceful future based on common values [...]. The Union contributes to the preservation and to the development of these common values while respecting the diversity of the cultures and traditions of the peoples of Europe ${ }^{104}$.

While the EU Charter makes no reference to the candidate countries, however, it could be argued that the idea of a larger union may be inferred from the reference to the "Peoples of Europe" rather than to "European citizens". Therefore, since "the Union is founded on the indivisible, universal values of human dignity, freedom, equality and solidarity"105 and the EU Charter is part of EU primary law, ${ }^{106}$ it applies even to the candidate countries wishing to join the EU.

The EU Charter is an integral part of EU primarily law and has an impact on the enlargement process. ${ }^{107}$ The candidate countries need to take into account the EU Charter in the context of their preparation for acceding to the EU. Article 49 TEU, concerning enlargement policy, asserts a clause for aspirant countries to respect and adhere to values referred in article 2 TEU. Thus, upholding human rights has become an essential element for aspirant countries. Reading jointly Arts 49 and

102 Judgment of 23 February 2013, Stefano Melloni v Ministerio Fiscal, Case C-399/11, EU:C:2013:107, para 60.

103 J. WOUTERS, 'The EU Charter of Fundamental Rights: Some Reflections on its External Dimensions' (2001) Vol. 8, Maastricht Journal of European and Comparative Law, p. 4.

104 EU Charter of Fundamental Rights, Recitals 1 and 3.

105 EU Charter of Fundamental Rights, Recital 2.

106 TEU, Art 6 (1).

107 J. MENÉNDEZ, 'Chartering Europe: Legal Status and Policy Implications of the Charter of Fundamental Rights of the European Union' (2002) Vol. 40, JCMS, pp. 471-490; W. SADURSKI, 'Charter and Enlargement' (2002) Vol. 8, European Law Review, 340-362. 
2 TEU, candidate countries shall become only European countries that are democratic and respect human rights. Consequently, it seems clear that the Charter should be taken into consideration as a benchmark when assessing human rights conditionality and will play an important role. More importantly, during the accession negotiation process of EU acquis, fundamental rights enumerated in the first cluster with the new enlargement strategy "Fundamentals" have to be assessed in light of the rights in the EU Charter, since the latter is part of the EU acquis. Candidate countries must ensure respect for fundamental rights citizens' rights, as guaranteed by the EU acquis and by the EU Charter.

\section{CONCLUSION}

As the paper demonstrated, the status of the human rights in the EU legal system has changed gradually. The founding Treaty did not contain any provisions on human rights promotion. The breaking point started with: i) the ECJ decision which recognized human rights as a general principle of community law and ii) the European Parliament commitment to include a human right clause in international agreement as a result of the massacre that occurred in Uganda. While these institutions recognized the importance of human rights, the Maastricht Treaty broadened the EU's discourse in human rights by moving the Union from an economic organization toward a political own having as its objective the promotion of human rights internally and externally. Since the Maastricht Treaty, the promotion of human rights has evolved in two aspects. Internally, human rights issues were recognized firstly, as a value on which the EU is founded and secondly, the introduction of the EU Charter as a legal binding document which is addressed to the institutions, bodies, offices and agencies of the Union when they are implementing Union law (Art 51). Externally, while the Maastricht Treaty introduced a reference to human rights, the Treaty of Lisbon considers upholding fundamental rights as the most effective instruments for spreading democracy, rule of law, promotion of human rights and protection of minorities and other values on which the Union is founded in third countries.

The EU enlargement policy has been considered as the most effective instrument in promotion of human rights in candidate countries. Any European states that commit itself to respect values on which the EU is founded, inter alia, respect of human rights, may join the EU once they have fulfilled the accession criteria. The paper argued that reading together treaty provisions on enlargement (Arts 49 and 2 TEU) and Copenhagen criteria, it is evident that the respect for human rights is no longer regarded solely as an eligibility condition (i.e. prerequisite for starting accession negotiations) as suggested by Article 49 (1) TEU but is also conceived as an integral part of the EU acquis which the candidate has to assimilate considered by the third Copenhagen criterion relating to the "candidate's ability to take on the obligations of membership". ${ }^{108}$ In this context, the candidate countries need to take into account the EU Charter, which is part of EU primary law, in the context of their preparation for acceding to the EU. The EU Charter does not add new requirements for membership but it increases social rights. The latter are not eligible conditions as stipulated by Copenhaghen criteria. As a conclusion, candidate countries must approximate their domestic legislation for fundamental rights citizens' rights, as guaranteed by the EU acquis and by the EU Charter and ensure proper implementation.

108 European Council, "Conclusion of the Presidency 21-22 June 1993". 
ACP-EEC First Convention signed at Lomé on 28 February 1975, OJ L 025, 30/01/1976

ACP-EEC Fourth Convention signed at Lomé on 15 December 1989 [1991] OJ L 229

ANASTASAKIS, O. 'The Europeanization of the Balkans' (2005) Vol.12, The Brown Journal of World Affairs

ARTS, K. Integrating Human Rights into Development Cooperation: The Case of the Lombe Convention, Springer, 2000

BARTEL, L. Human Rights and Democracy Clauses in the EU's International Agreements, DG for External Policies of the Union, 2005

BARTEL, L. Human Rights in the EU's International Agreement, Oxford university Press, 2005

BARTEL, L. Human Rights in the EU's International Agreement, Oxford university Press, 2005

BERRY, E. HOMEWOOD, M. J.and BOGUSZ, B. Complete EU Law: Text, Cases, and Materials, Oxford University Press, 2019, p. 416

BIEBER, F. 'Building Impossible States? State-Building Strategies and EU Membership in the Western Balkans' (2011) Vol. 63, Europe-Asia Studies

BULTERMAN, M. Human Rights in the Treaty Relations of the European Union, Insertia, 2001

BURLEY, A. M. and MATTLI, W. 'Europe Before the Court: A Political Theory of Legal Integration' (1993) Vol. 47, International Organization

Commission Communication to the Council and the European Parliament on the Stabilization and Association process for Countries of South - Eastern Europe [1999] COM 235

Commission, 'A more credible, dynamic, predictable and political EU accession process - Commission lays out its proposals' (Press release, 5 February 2020) < https://ec.europa.eu/commission/presscorner/detail/en/ IP_20_181> accessed 6 February 2020

Commission, 'Enhancing the accession process - A credible EU perspective for the Western Balkans' (Communication) $\operatorname{COM}(2020) 57$ final

Commission, 'Enlargement Strategy and Main Challenges 2013-2014' (Communication from the Commission to the European Parliament and The Council) COM (2013) 700 final

Commission, 'EU Enlargement Strategy' (Communication from the Commission to the European Parliament, the Council, the European Economic and Social Committee and the Committee of the Regions) COM (2015) 611 final

Commission, 'EU Enlargement Strategy' (Communication from the Commission to the European Parliament, the Council, the European Economic and Social Committee and the Committee of the Regions) COM (2015) 611 final

Commission, 'Remarks by Commissioner Olivér Várhelyi at the press conference on the revised enlargement methodology' <https://ec.europa.eu/commission/presscorner/detail/en/statement_20_208> accessed 6 February 2020

Commission, 2020 Communication on EU enlargement policy [2020] COM(2020) 660 final

Council Declaration on the situation in Uganda, 21 June 1977, Bull. EC, 6-1977, 2.2.59

Council Directive 64/221/EEC of 25 February 1964 on the co-ordination of special measures concerning the movement and residence of foreign nationals which are justified on grounds of public policy, public security or public health [1964] OJ Special edition 
Council of the European Union, Thessaloniki European Council 19 and 20 June 2003 Presidency Conclusions, Brussels, 1 October 2003

Council Regulation (EC) No 1085/2006 of 17 July 2006 establishing an Instrument for Pre-Accession Assistance (IPA) [2006] OJ L 210/82

Council Regulation (EC) No 2666/2000 of 5 December 2000 on assistance for Albania, Bosnia and Herzegovina, Croatia, the Federal Republic of Yugoslavia and the Former Yugoslav Republic of Macedonia, repealing Regulation (EC) No 1628/96 and amending Regulations (EEC) No 3906/89 and (EEC) No 1360/90 and Decisions 97/256/EC and 1999/311/EC [2000] OJ L 306/1

Council Regulation (EEC) No 3906/89 of 18 December 1989 on economic aid to certain countries of Central and Eastern Europe [1989] OJ L 375/11

CRAIG, P. and de BÚRCA, G. EU Law: Text, Cases, and Materials, $7^{\text {th }}$ edn, Oxford University Press

de BÚRCA, G. 'The Road not taken: The European Union as a Global Human Rights Actor' (2011) Vol. 105, The American Journal of International Law

DIMITROVA, A. L. 'The EU's Evolving Enlargement Strategies: Does Tougher Conditionality Open the Door for Further Enlargement?', Working Paper SERIES 30, MAXCAP, 2016

DUKE, S. The Elusive Quest for European Security, Palgrave Macmillan, 2000

DŽIHIĆ, V. and WIESER, A. 'Incentives for Democratisation? Effects of EU Conditionality on Democracy in Bosnia \& Hercegovina' (2011) Vol. 63, Europe-Asia Studies

EMMERT, F. and PETROVIĆ, S. 'The Past, Present, and Future of EU Enlargement' (2014) Vol. 37, Fordham International Law Journal

European Council, 'Cologne European Council 3-4 June 1999' (Conclusions of the Presidency) <https:// www.europarl.europa.eu/summits/kol1_en.htm> accessed 2 February 2021

European Council, 'Conclusion of the Presidency' (SN 180 / 1 / 93 Rev 1, 21 - 22 June 1993), <http://www. consilium.europa.eu/ueDocs/cms_Data/docs/pressData/en/ec/72921.pdf> accessed 31 January 2021

European Council, 'Conclusion of the Presidency' (SN 180 / 1 / 93 Rev 1, 21 - 22 June 1993), <http://www. consilium.europa.eu/ueDocs/cms_Data/docs/pressData/en/ec/72921.pdf> accessed 31 January 2021

European Council, 'Santa Maria da Feira European Council: Conclusions of the Presidency' (19 and 20 June 2000) <https://www.europarl.europa.eu/summits/fei1_en.htm> accessed 22 January 2021

European Council, “Presidency Conclusion” (Madrid, 15 and 16 December 1995) <http://www.consilium. europa.eu/uedocs/cms_data/docs/pressdata/en/ec/00400-C.EN5.htm> accessed 14 February 2021

FIERRO, E. The EU's Approach to Human Rights Conditionality in Practice, Martinus Hijhoff Publishers, 2002

Gerber, D. J. 'The Transformation of European Community Competition Law' (1994) Vol. 35, Harvard International Law Journal

GRABBE, $\mathrm{H}$. 'Six lessons of enlargement ten years on: the EU's transformative power in retrospect and prospect' (2014) Vol. 52, Journal of Common Market Studies

GRABBE, $\mathrm{H}$. The EU's Transformative Power: Europeanization through Conditionality in Central and Eastern Europe, Palgrave Studies in European Union Politics, Palgrave Macmillan, 2006

HAJDINI, B. and Skara, G. 'Lost in Implementation: EU Law Application in Albanian Legal System' (2017) Issue 33, Journal of Legal Studies 
HAJDINI, B. and Skara, G. 'Lost in Implementation: EU Law Application in Albanian Legal System' (2017) Issue 33, Journal of Legal Studies

Judgement of 15 July 1964, Flaminio Costa v E.N.E.L., C-6/64, [1964] ECLI:EU:C:1964:66

Judgement of 5 February 1963, NV Algemene Transport- en Expeditie Onderneming van Gend \& Loos v Netherlands Inland Revenue Administration, C-26/62, ECLI:EU:C:1963:1

Judgment of 12 December 1996, X, Joined Cases C-74/95 and C-129/95, ECLI:EU:C:1996:491

Judgment of 12 November 1969, Stauder v Stadt Ulm, C-29/69, ECLI:EU:C:1969:57

Judgment of 13 December 1979, Hauer v Land Rheinland-Pfalz, C-44/79, ECLI:EU:C:1979:290

Judgment of 13 December 1989, Oyowe and Traore v Commission, C-100/88, ECLI:EU:C:1989:638

Judgment of 14 May 1974, Nold KG v Commission, C-4/73, ECLI:EU:C:1974:51

Judgment of 14 May 1974, Nold KG v Commission, C-4/73, ECLI:EU:C:1974:51

Judgment of 14 October 2004, Omega, C-36/02, ECLI:EU:C:2004:614

Judgment of 15 July 1960, Präsident Ruhrkohlen-Verkaufsgesellschaft and Others v High Authority, C-3638/59 and C-40/59, ECLI:EU:C:1960:36

Judgment of 15 May 1986, Johnston v Chief Constable of the Royal Ulster Constabulary, C-222/84, ECLI:EU:C:1986:206

Judgment of 17 December 1970, Internationale Handelsgesellschaft mbH v Einfuhr- und Vorratsstelle für Getreide und Futtermittel, C-11/70, ECLI:EU:C:1970:114

Judgment of 17 February 1998, Grant v South West Trains Ltd, C-249/96, ECLI:EU:C:1998:63

Judgment of 18 September 1992, X v Commission, joined cases T-121/89 and T-13/90, ECLI:EU:T:1992:96

Judgment of 20 March 1984, Razzouk and Beydoun v Commission, Joined Cases C-75/82 and C-117/82, ECLI:EU:C:1984:116

Judgment of 22 December 2010, DEB Deutsche Energiehandels- und Beratungsgesellschaft $\mathrm{mbH} v$ Bundesrepublik Deutschland, C-279/09, ECLI:EU:C:2010:811

Judgment of 23 February 2013, Stefano Melloni v Ministerio Fiscal, Case C-399/11, EU:C:2013:107

Judgment of 27 October 1976, Prais v Council, C-130/75, ECLI:EU:C:1976:142

Judgment of 28 October 1975, Rutili v Ministre de l'intérieur. C-36/75, ECLI:EU:C:1975:137

Judgment of 4 February 1959, Storck v Haute autorité, C-1/58, ECLI:EU:C:1959:4

Judgment of 4 February 1959, Storck v Haute autorité, C-1/58, ECLI:EU:C:1959:4

Judgment of 6 February 1986, Castille v Commission, Joined cases C-173/82, C-157/83 and C-186/84, ECLI:EU:C:1986:54

Judgment of 7 June 1983, Musique Diffusion Française v Commission, Joined cases C-100-103/80, ECLI:EU:C:1983:158

Judgment of 8 July 1999, P Montecatini SpA v Commission, C-235/92, ECLI:EU:C:1999:362

Judgment of 8 October 1986, Staatsanwalt Freiburg v Keller, C-234/85, ECLI:EU:C:1986:377 
KARP, B. 'The Draft Constitution for a European Political Community' (1954) Vol. 8, International Organization

KÖRTVÉLYESI, Z. 'Inconsistency and Criticism: Mapping Inconsistency Arguments Regarding Human Rights Promotion in EU External Relations' (2016) European Yearbook of Human Rights

KUBICEK, P. J. 'International Norms, the European Union, and Democratization: Tentative Theory and Evidence' in Paul J Kubicek (ed), The European Union and Democratization, Routledge, 2003

LINOTTE, D. 'Corruption in the Balkans and EU Membership' (BiEPAG BLOG, 21 December 2019) <https:// biepag.eu/corruption-in-the-balkans-and-eu-membership/> accessed 21 January 2021

Lord GOLDSMITH QC, 'A Charter of Rights, freedoms and principles' (2001) Vol. 38, Common Market Law Review

MAMMADOV, A. 'Human Rights Promotion in the EU Foreign Policy' (Global Politics, 28 August 2010) <http://www.globalpolitics.cz/clanky/human-rights-promotion-in-the-eu-foreign-policy> accessed 29 December 2020

MENÉNDEZ, J. 'Chartering Europe: Legal Status and Policy Implications of the Charter of Fundamental Rights of the European Union' (2002) Vol. 40, JCMS

MILLER, V. The Human Rights Clause in the EU's External Agreement, House of Commons Library, International Affairs and Defence, 2004

MOBERG, A. 'What Constitutes a Breach of the EC's Conditionality Clause? < https://gup.ub.gu.se/v1/asset_ data/206701> accessed 29 December 2020

Opinion of Advocate General Mischo delivered on 20 September 2001, Booker Aquaculture Ltd trading as Marine Harvest McConnell and Hydro Seafood GSP Ltd v The Scottish Ministers, Joined Cases C-20/00 and C-64/00, ECLI:EU:C:2001:469, para 126

Regulation (EEC) No 1612/68 of the Council of 15 October 1968 on freedom of movement for workers within the Community [1968] OJ Special edition

Regulation (EU) No 231/2014 of the European Parliament and of the Council of 11 March 2014 establishing an Instrument for Pre-accession Assistance (IPA II) [2014] L 77/11

Regulation (EU) No 231/2014 of the European Parliament and of the Council of 11 March 2014 establishing an Instrument for Pre-accession Assistance (IPA II) [2014] OJ L 77/11

Resolution 14 'Adopted on 10 September 1952 at Luxembourg by the six Ministers for Foreign Affairs' <http:// aei.pitt.edu/991/1/political_union_draft_treaty_1.pdf> accessed 22 January 2021

ROSAS, A. 'Is the EU a Human rights Organisation' CLEER Working Paper 2011/1

SADURSKI, W. 'Charter and Enlargement' (2002) Vol. 8, European Law Review

SCHIMMELFENNING, F. 'Competition and community: constitutional courts, rhetorical action, and the institutionalization of human rights in the EU Union' (2006) Vol. 13, Journal of EU Public Policy

SKARA, G. 'The Rocky Road of Western Balkan Countries toward European Integration: The Need for a Credible and Effective Approach' (2020) Vol.3, Journal of European Social Research

SKARA, G. 'The Role of The Role of the EU as a Peacebuilder in the Western Balkans' (2014) Vol. 14, Romanian Journal of European Affairs

SMITH, K. E. European Union Foreign Policy in a Changing World, $3^{\text {rd }}$ edition, Polity Press, 2014

SMITH, K. E. European Union Foreign Policy in a Changing World, $3^{\text {rd }}$ edition, Polity Press, 2014 


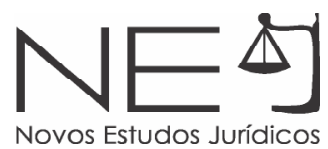

SPAVENTA, E. 'Fundamental Rights in the European Union' in Catherine Barnard and Steve Peers (eds), European Union Law, $3^{\text {rd }}$ edition, Oxfrod University Press, 2020

Stabilisation and Association Agreement between the European Communities and their Member States, of the one part, and the former Yugoslav Republic of Macedonia, of the other part, [2004] OJ L 84/13

Stabilisation and Association Agreement between the European Communities and their Member States, of the one part, and the Republic of Albania, of the other part [2009] OJ L 107/166

Stabilisation and Association Agreement between the European Communities and their Member States of the one part, and the Republic of Serbia, of the other part [2013] OJ L 278/16

Stabilisation and Association Agreement between the European Communities and their Member States of the one part, and the Republic of Montenegro, of the other part [2010] OJ L108/3

Stabilisation and Association Agreement between the European Communities and their Member States, of the one part, and Bosnia and Herzegovina, of the other part [2015] OJ L 164/2

Stabilisation and Association Agreement between the European Union and the European Atomic Energy Community, of the one part, and Kosovo*, of the other part [2016] OJ L 71/3

The Treaty on European Union, as signed in Maastricht on 7 February 1992

The World Bank and WIIW, 'Western Balkans Labor Market Trends 2020', SEE Jobs Gateway March 2020

Treaty Establishing the European Economic Community (EEC Treaty) [1957] OJ Special edition

Treaty of Amsterdam amending the Treaty on European Union, the Treaties establishing the European Communities and certain related acts - Final Act [1997] OJ C 340/01

UVIN, P. 'Do as I say, not as I do: The Limits of Political Conditionality' in George Sorensen (ed), Political Conditionality, Frank Cass, 1993

VELLUTI, S. 'The Promotion and Integration of Human Rights in EU External Trade Relations' (2016) Vol. 32, Utrecht Journal of International and European Law

WEILER, H.H. J. 'Eurocacy and Distrust: Some Questions Concerning the Role of the European Court of Justice in the Protection of Fundamental Human Rights Within the Legal Order of the European Communities' (1986) Vol. 61, Washington Law Review

WETZEL, J. E. (ed). The EU as a “Global Player" in Human Rights? Routledge, 2011

WOUTERS, J. 'The EU Charter of Fundamental Rights: Some Reflections on its External Dimensions' (2001) Vol. 8, Maastricht Journal of European and Comparative Law

YOUNGS, R. 'Engaging: sharpening European influence. In New terms of engagement', in Richard Young (ed), Global Europe Report 2: New Terms of Engagement, The Foreign Policy Centre, 2004

Zagreb Summit, (Final declaration, November 2000) <http://www.consilium.europa.eu/ueDocs/cms_Data/ docs/pressdata/en/er/Declang4.doc.html> accessed 20 January 2021

ZOLKOS, M. M. 'Bringing Human Rights in the Enlargement Politics: the EU as a Human Rights Promoter in the Central Eastern Europe' [2004] Středoevropské politické studie < https://journals.muni.cz/cepsr/article/ view/4044/5283> accessed 1 March 2021

Recebido em: 08/02/2021

Aprovado em: 14/04/2021

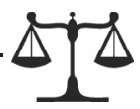

